\title{
Pemasaran produk UMKM melalui media sosial dan e-commerce
}

\author{
Putri Trulline \\ Universitas Padjadjaran, Bandung, Indonesia
}

\begin{abstract}
ABSTRAK
Pada krisis yang terjadi tahun 1998 para pelaku Usaha Mikro Kecil dan Menengah (UMKM) tidak terdampak secara signifikan bahkan menjadi penopang dalam menjaga kestabilan ekonomi nasional. Akan tetapi, pada masa pandemi Covid-19 semua sektor merasakan gejolak tidak terkecuali para pelaku UMKM yang justru paling merasakan dampaknya. Kehadiran media sosial dan e-commerce tentu dapat membantu para pelaku UMKM untuk dapat tetap bertahan dan memasarkan produknya di masa pandemi Covid-19. Penelitian ini bertujuan untuk mengetahui bagaimana para pelaku UMKM memanfaatkan media sosial dan e-commerce dalam memasarkan produknya di masa pandemi Covid-19. Metode yang digunakan dalam penelitian ini ialah metode deskriptif kualitatif. Teknik pengumpulan data yang dilakukan dengan wawancara, observasi, focus group discussion dan studi literatur, key informant dalam penelitian ini ialah pelaku UMKM bidang kuliner di beberapa kota di Jawa Barat, account executive Gojek dan akademisi. Hasil penelitian menunjukkan bahwa para pelaku UMKM bidang kuliner sudah mulai menggunakan media sosial seperti instagram dan e-commerce seperti Gofood dan GrabFood untuk memasarkan produknya, beberapa pelaku UMKM bahkan sudah sangat menguasai berbagai fitur yang ada di sosial media seperti Instagram yang diperuntukan untuk bisnis, sumberdaya yang dimiliki pelaku UMKM menjadi salah satu faktor yang menentukan bagaiman media sosial dan e-commerce ini dapat di kelola dengan baik yang berimplikasi pada kemungkinan terjadinya kenaikan omset, pengelolaan media sosial dan e-commerce yang baik pun diakui oleh para pelaku UMKM dapat mengingkatkan omset penjualan di tengah pandemi Covid-19 yang terjadi saat ini.
\end{abstract}

Kata-kata kunci: Media sosial; e-commerce; Instagram; UMKM; Pandemi Covid-19

\section{Marketing of MSME products through social media and e-commerce}

\begin{abstract}
In the crisis that occurred in 1998, the actors of Micro, Small and Medium Enterprises (MSMEs) were not significantly affected and even became a support in maintaining national economic stability. However, during the Covid-19 pandemic, all sectors felt the impact, including MSME players who felt the impact the most. The presence of social media and e-commerce can certainly help MSME players to be able to survive and market their products during the Covid-19 pandemic. This study aims to determine how MSME actors use social media and e-commerce to market their products during the Covid-19 pandemic. The method used in this research is a qualitative descriptive method, data collection techniques are carried out by interviews, observation, focus group discussions and literature studies, the key informants in this study are SMEs in the culinary field in several cities in West Java, Gojek account executives and academics. The results showed that the culinary sector MSME actors have started using social media such as Instagram and e-commerce such as Gofood and GrabFood to market their products, some MSMEs have even mastered various features on social media such as Instagram which are intended for business, resource MSME players have become one of the factors that determine how social media and e-commerce can be managed properly which has implications for the possibility of an increase in turnover, good management of social media and e-commerce is also recognized by MSME actors to increase sales turnover in the midst of a pandemic. the current Covid-19.
\end{abstract}

Keywords: Social media; e-commerce; Instagram; UMKM; the Covid-19 pandemic

Korespondensi: Putri Trulline, S.I.Kom., M.I.Kom. Fakultas Ilmu Komunikasi Universitas Padjadjaran. J1 Raya Bandung Sumedang Km 21.Email:putri.trulline@unpad.ac.id 


\section{PENDAHULUAN}

Krisis yang terjadi pada tahun 1998 tidak memberikan dampak yang signifikan bagi para pelaku Usaha Mikro Kecil dan Menengah (UMKM) bahkan kehadirannya menjadi andalan dalam menjaga pertumbuhan ekonomi nasional. Namun pada masa pandemi covid-19 semua sektor terdampak tidak terkecuali para pelaku UMKM yang justru paling merasakan dampaknya. Pandemi covid-19 yang berasal dari Wuhan China telah menyebar hampir ke seluruh dunia. Hampir 200 negara termasuk Indonesia. Dampak pandemi tersebut menimbulkan krisis di berbagai sektor, baik di bidang kesehatan, pendidikan, dan ekonomi (Consulting, 2020). Di bidang kesehatan, pelayanan kesehatan baik di rumah sakit maupun sarana pelayanan kesehatan lainnya sangat kewalahan dalam menerima lonjakan jumlah pasien Covid-19. Bidang pendidikan, kebijakan pembelajaran online tanpa tatap muka mengakibatkan peserta didik tidak memperoleh pembelajaran yang optimal (Harnani, 2020; Nguyen \& Pham, 2020).

Bidang ekonomi dampak Covid-19 lebih terasa, banyak perusahaan yang memberhentikan karyawannya karena produksi menurun, bahkan banyak usaha yang tutup karena terjadi penurunan penjualan. Salah satu dampak ekonomi dari Covid-19 adalah pada pelaku UMKM. UMKM memainkan peran penting dalam perekonomian Indonesia. Kementerian Koperasi dan Usaha Kecil dan Menengah (Kemenkop UKM) melaporkan pada 2018 jumlah UMKM di Indonesia sekitar 64.194.057 unit, dengan daya serap total 116.978.631 tenaga kerja. Angka tersebut setara dengan 99\% dari total unit usaha di Indonesia, dengan persentase penyerapan tenaga kerja di sektor ekonomi setara dengan $97 \%$. Sementara itu, 3\% sisanya dibagi menjadi sektor industri besar. UMKM memberikan konstribusi sebesar $60 \%$ pada pertumbuhan nasional atau PDB secara nasional dan menyerap 90\% tenaga kerja. Terjadinya Pandemi Covid-19 menyebabkan pemerintah mengeluarkan kebijakan pembatasan baik dalam perjalanan, aktivitas maupun aktivitas yang mengundang keramaian. Kebijakan yang disebut Pembatasan Sosial Skala Besar atau PSBB menyebabkan kegiatan ekonomi melambat atau bahkan terhenti. Sektor UMKM yang mengandalkan kegiatan ekonomi seharihari tentunya paling terpengaruh (Sugiri, 2020).

Penelitian ini bertujuan mengkaji strategi yang digunakan oleh UMKM dalam rangka bertahan dan tumbuh kembali di masa pandemi Covid19. Obyek penelitian adalah pelaku UMKM yang mengalami dampak langsung masa pandemi. Metode yang digunakan adalah studi Pustaka atau studi. Penelitian ini mengungkapkan bahwa pada masa pandemi konsumen nyaris lupa dengan 
merek, maka komunikasi melalui iklan digital akan meningkatkan kembali brand awareness (Sugiri, 2020). Perilaku digital mendorong perluasan konsumen online bukan lagi pada generasi milenial. Beberapa UMKM telah mengalami bangkrut. Namun tidak sedikit yang akhirnya bangkit dan kemudian bertumbuh. UMKM mengubah operasional produksi dengan mengurangi jumlah produksi dan sekaligus melakukan inovasi untuk menambah daya saing. Di sisi lain penggunaan digital marketing secara massif telah dilakukan untuk meningkatkan awareness pelanggan (DiezMartin, 2019). Marketplace sebagai bentuk manifestasi dari e-commerce digunakan sebagai inovasi atau perubahan metode penjualan (Santoso, 2020).

Jika dalam penelitian tersebut berfokus pada bagaimana awarness konsumen tetap bisa dibangun walaupun pada masa pandemi Covid-19 seperti saat ini sedangkan dalam penelitian ini peneliti berfokus pada sejauh mana para pelaku UMKM memanfaatkan media sosial dan e-commerce nya dalam memasarkan produk.

Pedagang kecil yang mengandalkan aktivitas penjualan sehari-hari dari masyarakat akan mengalami penurunan omset karena tidak ada yang membelanjakan uangnya. Di bidang kuliner, banyak pengusaha restoran seperti warteg yang menutup usahanya karena konsumen tidak makan di restoran mereka. Pengusaha kecil juga akan kesulitan memasarkan dan mendapatkan bahan baku untuk proses produksi.

Kondisi yang sama juga terjadi di Jawa Barat (Jabar). Sehingga menjaga UMKM tetap tumbuh dan tangguh pasca pandemi, menjadi tantangan besar bagi semua pihak agar krisis kesehatan tidak merembet pada krisis ekonomi. Gubernur Jabar Ridwan Kamil mengungkapkan sejak awal Juni 70\% usaha ekonomi sudah mulai diperbolehkan agar sektor UMKM kembali bergerak. Namun ia berpesan agar UMKM siap dengan era disrupsi, melalui digitalisasi usaha. (Jabarprov.go.id, 2020). Meskipun UMKM sudah menampilkan peranannya dalam perekonomian nasional, tetapi masih mengalami bermacam hambatan, baik berupa hambatan internal ataupun eksternal, dalam hal pengelolaan, pemasaran, penguasaan teknologi, dan permodalan.

Pandemi Covid-19 telah mengubah kebiasaan baik konsumen maupun produsen (Soetjipto, 2020). Perubahan perilaku tersebut tidak lepas dari aturan yang berlaku saat masa pandemi yang mengaharuskan setiap individu melakukan physical distancing. Semua orang enggan untuk keluar, berkerumun, dan bahkan aktifitas mereka pun dibatasi. Segala keterbatasan tersebut pada akhirnya juga memberi dampak serius pada pelaku Bisnis. 
Interaksi sosial kemasyarakatan menjadi nyaris putus di masa pandemi. Interaksi sosial terbatas pada sekat dan ruang dunia maya seperti media sosial.

Media sosial dapat dikelompokkan menjadi setidaknya enam jenis, yaitu: Sebuah situs web yang memungkinkan pengguna untuk mengubah, menambah atau menghapus konten di situs web (Kaplan \& Haenlein, 2010). Blog atau mikro blog yang memberikan kebebasan penggunanya untuk mengekspresikan sesuatu di blog, misalnya Twitter. Konten adalah aplikasi yang memungkinkan pengguna untuk berbagi informasi (konten) dalam bentuk video, e-book dan gambar, misalnya YouTube, Instagram. Situs jejaring sosial adalah aplikasi yang menghubungkan pengguna situs jejaring sosial untuk terhubung dan berbagi informasi, baik informasi publik maupun privat, misalnya Facebook (Rahadi, 2017). Dunia game virtual adalah aplikasi yang memungkinkan pengguna untuk mereplikasi lingkungan dalam bentuk tiga dimensi (3D) untuk berinteraksi dengan orang lain seperti di dunia nyata, contoh dari aplikasi ini adalah game online. Dunia sosial virtual yang memiliki konsep yang hampir sama dengan dunia game virtual namun dalam konteks yang lebih bebas misalnya adalah aplikasi second life (Dirgantara \& Sambodo, 2015).

Definisi pemasaran, menurut (Kotler, 2014) adalah proses sosial dan manajerial di mana individu dan kelompok mendapatkan apa yang mereka butuhkan dan inginkan dengan menciptakan, menawarkan, dan bertukar produk dengan pihak lain. Pengertian Pemasaran menurut Boyd bahwa Pemasaran adalah "Suatu proses sosial yang melibatkan aktivitas penting yang memungkinkan individu dan perusahaan mendapatkan apa yang mereka butuhkan dan inginkan melalui pertukaran dengan pihak lain dan mengembangkan hubungan pertukaran" (Boyd, 2000).

Pengertian dari bauran pemasaran menurut Swastha bahwa Bauran Pemasaran merupakan "gabungan dari empat variabel aktivitas yang merupakan inti dari sistem pemasaran perusahaan yaitu produk, struktur harga, aktivitas promosi, dan sistem distribusi (Swastha, 2002). Produk memiliki pengertian menurut Kotler adalah segala sesuatu yang dapat ditawarkan ke pasar untuk memenuhi kebutuhan (Kotler, 2014). Produk yang dipasarkan meliputi barang fisik, jasa, orang, tempat, organisasi, dan gagasan. Lima tingkatan produk dalam merencanakan suatu penawaran atau produk, pemasar perlu memahami lima tingkatan produk, yaitu: Produk utama adalah manfaat yang benar-benar dibutuhkan atau akan dikonsumsi oleh pelanggan dari setiap produk, produk generik adalah produk dasar yang dapat memenuhi fungsi produk paling dasar, harapan produk adalah produk formal 
yang ditawarkan dengan berbagai atribut, dan kondisi secara formal diharapkan dan disepakati untuk dibeli, produk pelengkap, yaitu ragam produk, atribut menyindir atau ditambah dengan berbagai manfaat dan layanan sehingga dapat memberikan kepuasan tambahan dan dapat dibedakan dengan produk pesaing, Produk potensial adalah segala macam penambahan dan perubahan yang mungkin akan dikembangkan untuk suatu produk di masa yang akan datang. Atribut produk merupakan elemen produk yang dianggap penting oleh konsumen dan digunakan sebagai dasar pengambilan keputusan pembelian, dan atribut produk meliputi merek, kemasan, pelabelan, layanan pelengkap, dan jaminan.

Harga menurut Swastha adalah "jumlah (ditambah beberapa barang jika memungkinkan) yang dibutuhkan untuk mendapatkan kombinasi barang dan jasanya" (Swastha, 2002). Harga adalah jumlah uang yang harus dikeluarkan konsumen untuk mendapatkan suatu produk. Harga merupakan satu-satunya elemen bauran pemasaran yang memberikan pendapatan atau pendapatan bagi perusahaan sedangkan tiga elemen lainnya (produk, tempat, promosi) menimbulkan biaya. Berbeda dengan karakteristik produk saluran distribusi, kedua hal ini tidak dapat diubah atau disesuaikan dengan mudah dan cepat, karena biasanya melibatkan keputusan jangka panjang.
Faktor penentu utama dalam penetapan harga adalah tujuan pemasaran perusahaan (Batubara \& Hidayat, 2016). Tujuan tersebut dapat berupa maksimalisasi keuntungan, menjaga kelangsungan hidup perusahaan, menambah pangsa pasar yang besar, menjadikan kepemimpinan dalam hal kualitas, mengatasi persaingan, menerapkan tanggung jawab sosial.

Salah satu komponen bauran pemasaran adalah harga. Sehingga harga perlu didukung dan dikoordinasikan satu sama lain dengan komponen bauran pemasaran lainnya yaitu promosi, produk, dan distribusi. Biaya merupakan faktor penentu harga minimum yang harus ditetapkan agar perusahaan tidak mengalami kerugian (Soei \& Abijono, 2014). Oleh karena itu, setiap perusahaan harus sangat memperhatikan aspek struktur biaya (variabel dan tetap), serta jenis biaya lainnya seperti biaya peluang, biaya terkendali, biaya saku, biaya tambahan, dan biaya penggantian.

Tempat menurut Kotler atau Place adalah "Kegiatan perusahaan yang membuat produk tersedia sesuai target". Tempat adalah saluran distribusi, serangkaian organisasi yang saling bergantung yang terlihat satu sama lain dalam proses membuat produk atau layanan siap digunakan atau dikonsumsi (Kotler, 2014). Lokasi artinya berkaitan dengan tempat perusahaan harus berbasis dan melakukan operasi. Dalam hal ini terdapat tiga jenis 
interaksi yang mempengaruhi lokasi, yaitu: Konsumen datang ke perusahaan jika situasinya seperti ini, maka lokasi menjadi sangat penting. Perusahaan sebaiknya memilih tempat yang dekat dengan konsumen agar mudah dijangkau. Dengan kata lain harus strategis. Perusahaan yang mendatangi konsumen merupakan lokasi yang tidak terlalu penting, namun yang harus diperhatikan adalah penyampaian layanan harus tetap berkualitas, perusahaan (penyedia jasa) dan konsumen tidak bertemu secara langsung adalah penyedia jasa, dan konsumen berinteraksi melalui sarana tertentu seperti telepon, komputer, atau surat (Swastha, 2002). Dalam hal ini, lokasi menjadi sangat kecil selama komunikasi antara kedua pihak dapat berlangsung. Baik lokasi maupun saluran yang dipilih sangat bergantung pada kriteria pasar dan sifat layanan itu sendiri. Misalnya dalam jasa pengiriman barang, jika pasar menginginkan pengiriman cepat dan tepat waktu serta sifat barang yang tidak tahan lama, maka lokasi yang dipilih harus menjadi strategi, dan saluran penjualan harus langsung dikendalikan.

Promosi dapat dianalogikan dengan sebagus apapun kualitas suatu produk, seberapa menarik tampilannya atau seberapa besar manfaatnya, jika tidak ada yang mengetahui keberadaannya maka mustahil untuk membeli produk tersebut (Shintarani, 2018). Konsumen tidak dapat mengenali produk yang sudah bagus dengan harga yang bagus, sehingga produk tersebut tidak akan berhasil di pasaran. Sarana dan prasarana diperlukan secara efektif agar informasi tentang keberadaan suatu produk dapat menjangkau masyarakat atau konsumen. Upaya memperkenalkan produk kepada konsumen merupakan awal dari kegiatan promosi. Kotler mendefinisikan promosi sebagai aktivitas yang dilakukan oleh perusahaan untuk mengkomunikasikan manfaat produknya dan meyakinkan konsumen untuk membeli (Kotler, 2014). Julian mendefinisikan promosi sebagai rangkaian teknik yang digunakan untuk mencapai tujuan penjualan atau pemasaran dengan menggunakan biaya yang efektif, dengan menambahkan nilai pada produk atau layanan kepada perantara atau pengguna langsung (Cummins, 1991). Biasa kegiatan ini tidak dibatasi dalam jangka waktu tertentu.

Bauran promosi adalah program komunikasi pemasaran total perusahaan yang terdiri dari iklan, penjualan pribadi, promosi penjualan, dan hubungan masyarakat yang digunakan perusahaan untuk mencapai tujuan periklanan dan pemasarannya (Tjiptono, 2002). Menurut perpaduan antara personal selling dan alat promosi lainnya, kesemuanya direncanakan untuk mencapai program penjualan. Bauran promosi terdiri dari: Advertising (periklanan) yaitu segala biaya yang harus dikeluarkan 
oleh sponsor untuk melakukan presentasi dan promosi non personal berupa ide, barang, dan jasa. Personal selling, yaitu presentasi pribadi oleh tenaga penjual perusahaan untuk menyukseskan penjualan dan membangun relasi dengan pelanggan. Promosi penjualan, yaitu insentif jangka pendek untuk mendorong pembelian atau penjualan suatu produk atau jasa. Humas (public relations) yaitu seperti membangun hubungan baik dengan publik terkait untuk mendapatkan dukungan, membangun "citra perusahaan". Dan tangani atau singkirkan gosip, cerita, dan peristiwa yang dapat merugikan. Pemasaran langsung (direct marketing) yaitu komunikasi langsung dengan beberapa konsumen sasaran untuk memperoleh tanggapan langsung dengan beberapa konsumen sasaran untuk memperoleh tanggapan langsung dengan menggunakan surat, telepon, faximile, email, dll untuk berkomunikasi secara langsung dengan konsumen atau bisnis tertentu untuk menerima secara langsung. tanggapan.

Pemasaran digital adalah praktik pemasaran yang menggunakan saluran distribusi digital untuk menjangkau konsumen dengan cara yang relevan, pribadi, dan hemat biaya (Satyo, 2009). Kegiatan pemasaran akan dilakukan secara intensif dengan menggunakan media komputer, baik dari penawaran produk, pembayaran, dan pengiriman.

Dalam konteks pemasaran, kondisi krisis global membuat banyak organisasi mulai memikirkan dan mencari cara efisiensi . Bukan rahasia lagi bahwa biaya tertinggi organisasi selalu berasal dari biaya pemasaran dan tenaga kerja. Oleh karena itu organisasi bisnis harus pandai melihat peluang kegiatan pemasaran yang efektif di era digital dengan biaya yang murah dan efektif (Nurpratama, 2020).

Perilaku konsumen mulai bergeser, dan konsumen mulai menggunakan Internet untuk berbagai keperluan mulai dari mencari berita dan informasi, email, berbagai file, foto, mendengarkan musik, menonton film, dan lain sebagainya. Kondisi ini dipercepat dengan munculnya berbagai situs ekspresif media sosial seperti Blog, Facebook, YouTube, Twitter, dan lain sebagainya. Orang-orang semakin terhubung dan komunitas berkembang. Mereka mulai mengubah aturan permainan dan menjadi pemberi pengaruh di komunitas mereka. Para anggota akan lebih mendengarkan saran dari sesama komunitas daripada karakter dan iklan. Jika dulu hanya tokoh atau artis yang menjadi influencer, kini semua orang bisa menjadi influencer (Supriyono, 2020).

Belanja online diartikan sebagai perilaku mengunjungi toko online melalui media Internet untuk mencari, menawar, atau melihat produk untuk membeli dan memperoleh produk. Belanja online terjadi ketika pelanggan memilih Internet untuk bertransaksi karena 
banyak faktor yang memotivasi pelanggan untuk membeli. Berbelanja melalui Internet menawarkan keuntungan unik. Dengan berbelanja melalui Internet pembeli dapat melihat terlebih dahulu barang dan jasa yang ingin dibelanjakannya melalui web yang dipromosikan oleh penjual. Kegiatan belanja ini merupakan salah satu bentuk komunikasi baru yang tidak membutuhkan komunikasi tatap muka secara langsung. Namun demikian, ini dapat dilakukan secara terpisah dari dan ke seluruh dunia melalui media Notebook, Komputer, atau Handphone yang terkoneksi dengan layanan Internet. Dalam konteks toko online, secara umum pengguna Internet dapat diklasifikasikan menjadi tiga jenis pengguna; Bukan pembelian, browser, dan Pembeli.

Teknologi kewirausahaan merupakan wahana yang memfasilitasi individu, organisasi bisnis, daerah, negara menuju kemakmuran, dan karenanya menjadi kepuasan intelektual ketika kita membahasnya. Menurut definisi, teknologi kewirausahaan adalah proyek investasi dengan mengumpulkan individuindividu khusus dan mengumpulkan aset heterogen yang terkait dengan kemajuan ilmu pengetahuan dan teknologi untuk menciptakan nilai perusahaan. Ada empat dimensi teknologi kewirausahaan: hasil akhir, target hasil akhir, mekanisme yang digunakan untuk memberikan hasil akhir, saling ketergantungan mekanisme ini dengan kemajuan ilmu pengetahuan dan teknologi. Pemasaran digital adalah pemasaran yang menggunakan penerapan teknologi digital.

Salah satu bentuk pemasaran digital dengan menggunakan media elektronik atau Internet adalah pemasaran Internet (e-marketing).

E-marketing adalah proses pemasaran yang menggunakan teknologi komunikasi elektronik, khususnya internet. Peran strategi pemasaran digital dapat menjadi penting dalam mengikuti perkembangan teknologi digital dan mengembangkan rencana untuk menarik konsumen dan mengarahkannya ke kombinasi komunikasi elektronik dan komunikasi tradisional.

Manfaat media sosial untuk pemasaran adalah cara mudah untuk mengenal lebih banyak pelanggan, dan lebih dekat dengan mereka, tidak hanya itu dengan media sosial kita dapat menemukan target konsumen dengan lebih efektif misalnya dengan strategi demografis seperti membidik konsumen berdasarkan usia, lokasi, dan sebagainya seperti facebook dan Twitter, kedua contoh yang dimiliki perangkat ini.

Dan dengan social media kita bisa memperluas target market kita dan mencari konsumen baru, salah satu contohnya adalah dengan memanfaatkan \#hashtags yang berhubungan dengan bisnis kemudian digunakan untuk mendapatkan calon customer 
yang sesuai. dengan mengikuti dan like atau mengomentari postingan agar mereka mengetahui merk dan produk yang akan ditawarkan kepada konsumen. Dan konsumen dapat memberikan umpan balik yang berkaitan langsung dengan bisnis yang kita jalani sehingga kita dapat mengetahui secara persis apa yang dibutuhkan oleh konsumen. Masih terkait dengan manfaat media sosial tentang fan page di facebook dengan fasilitas fan page konsumen dapat langsung mengirimkan saran, kritik, dan pesan tentang produk, dengan media sosial kita mampu mengembangkan target pasar lebih cepat dengan kompetitor, meningkatkan pengunjung website dan mesin pencari peringkat, membantu konsumen dapat menjangkau bisnis.

Penelitian berikut menyatakan bahwa seluruh pelaku UMKM menyatakan bahwa penggunaan digital marketing memberikan manfaat yaitu dapat berinteraksi dan menginformasikan secara langsung kepada konsumen (Febriyantoro \& Arisandi, 2018). Pelaku UMKM mengatakan bahwa penggunaan digital marketing memperluas pangsa pasarnya, meningkatkan kesadaran konsumen karena UKM rutin update informasi produk setiap hari dan meningkatkan penjualan karena beberapa UMKM juga bekerjasama dengan beberapa marketplace seperti Shopee dan Tokopedia.

Instagram adalah platform media sosial dengan identitas unik dan memiliki estetika. E-commerce sendiri diartikan sebagai sekumpulan teknologi dinamis, aplikasi dan proses bisnis yang menghubungkan perusahaan, konsumen dan komunitas tertentu melalui transaksi elektronik. Perdagangan barang, jasa dan informasi dilakukan secara elektronik. Pengembangan sistem e-commerce bagi UMKM bertujuan untuk mengubah budayanya yang masih mengandalkan pembelian konvensional menjadi belanja online, meningkatkan penjualan UMKM dalam rangka mempromosikan, memasarkan dan menjual produk kepada pengguna Internet melalui website tanpa ada batasan ruang dan waktu. Namun sayangnya masih sedikit dari para pelaku UMKM yang memanfaatkan media sosial tersebut. Dari uraian latar belakang permasalahan tersebut maka tujuan penelitian ini adalah mengetahui bagaimana para pelaku UMKM memanfaatan media sosial dan e-commerce dalam memasarkan produknya di masa pandemi Covid-19

\section{METODE PENELITIAN}

Metode yang digunakan dalam penelitian ini ialah deskriptif kualitatif yakni sebuah metode yang mencoba menerangkan serta menganalisis fenomena, kejadian, dinamika sosial, perilaku, serta anggapan seorang ataupun kelompok terhadap sesuatu. 
"Qualitative research is an inquiry process of understanding based on distinct methodological traditions of inquiry that explore a social or human problem. The researcher builds a complex, holistic picture, analyzes words, reports detailed views of informants, and conducts the study in a natural setting" (Creswell, 2018).

Dalam hal ini pandemi Covid-19 merupakan fenomena sosial yang menarik untuk diteliti dan seperti apa dan bagaimana para pelaku UMKM memanfaatan media sosial dan e-commerce dalam memasarkan produknya. Penelitian ini juga menggunakan metode studi pustaka dalam menganalisis teori-teori ataupun konsep yang relevan dengan objek penelitian. kemudian dilakukan penilaian terhadap konsep dan teori yang digunakan berdasarkan literatur yang tersedia. Analisis kepustakaan digunakan untuk menghasilkan ide atau hipotesis yang menjadi landasan kajian penelitian.

Key informan dalam penelitian ini ialah pelaku usaha UMKM yang berjumlah 40 mitra UMKM bidang kuliner, yang berada di beberapa kota di Jawa Barat yang merupakan mitra pada pelaksanaan KKN Virtual yang berlangsung dari bulan Januari sampai dengan Februari 2021. Dari 40 mitra tersebut yang dijadikan fokus dalam penelitian ini ialah mereka yang sudah dalam taraf advance, dalam memanfaatkan media sosial dan e-commerce untuk memasarkan produknya di masa pandemi Covid-19 dengan alasan peneliti ingin melihat sejauh mana efektivitas yang dirasakan oleh para pelaku UMKM dalam mengelola dan mengembangkan media sosial dan e-commerce, yakni sebanyak 5 (lima) pelaku UMKM bidang kuliner selain itu ada juga account executive dari Gojek yang membina UMKM yang tergabung di wilayah Jawa Barat, serta akademisi.

Teknik pengumpulan data dalam penlitian ini ialah menggunakan observasi, wawancara, focus group discussion dan studi literatur. Teknik analisis data dilakukan dengan cara memaparkan hasil temuan di lapangan kemudian di analisis dengan berbagai konsep yang terkait dengan penelitian ini.

\section{HASIL DAN PEMBAHASAN}

Saat ini istilah digital marketing atau pemasaran digital menjadi salah satu istilah yang mungkin membuat sebuah bisnis terdengar lebih canggih. Istilah ini mulai populer digunakan di awal tahun 2000-an, pemasaran digital sebenarnya sudah ada sejak. Jika dirunut lebih jauh, usianya bahkan 100 tahun lebih tua (Kannan \& Li, 2017).

Guglielmo Marconi, penemu radio, dianggap sebagai orang pertama yang membuat orang berpikir tentang pemasaran digital. Pada tahun 1986, Marconi menunjukkan kepada publik bagaimana sinyal dapat dikirim tanpa kabel. Inilah asal mula radio seperti yang kita kenal sekarang. Penemuan radio tentunya 
tidak serta merta bermuara pada munculnya pemasaran digital. Butuh waktu hingga 10 tahun agar teknologi radio bisa diperkenalkan secara luas ke publik. Dan tentunya tidak butuh waktu lama hingga masyarakat menyadari bahwa teknologi baru ini bisa digunakan sebagai alat pemasaran alias marketing.

Pemasaran digital adalah operasi pemasaran atau periklanan dari suatu merek atau produk menggunakan media digital atau Internet. Tujuan pemasaran digital adalah untuk menjangkau pelanggan dan konsumen masa depan dengan cepat.

Pandemi covid-19 telah memberikan guncangan luar biasa di sektor ekonomi, termasuk UMKM. Adanya kebijakan pembatasan sosial berskala besar (PSBB) telah membatasi pergerakan masyarakat, yang juga menyebabkan siklus ekonomi masyarakat menjadi stagnan. Orang akan menahan diri untuk tidak membelanjakan uang mereka karena mereka lebih banyak di rumah. Hal ini tentunya berdampak besar pada sektor UMKM yang sangat bergantung pada omset yang mereka peroleh sehari-hari. Oleh karena itu, adanya media sosial dan e-commerce sebagai bagian dari digital marketing akan sangat membantu para pelaku UMKM untuk tetap bertahan di masa pandemi saat ini.

Usaha Mikro, Kecil, dan Menengah (UMKM) merupakan kegiatan usaha yang mampu memperluas lapangan kerja dan memberikan pelayanan ekonomi secara luas kepada masyarakat, berperan dalam proses pemerataan dan peningkatan pendapatan masyarakat, mendorong pertumbuhan ekonomi, dan mewujudkan stabilitas ekonomi nasional. Kriteria usaha yang termasuk dalam Usaha Kecil dan Menengah (UKM) telah diatur dalam sistem peraturan perundang-undangan yang berdasarkan undang-undang. Berdasarkan Undang-Undang Nomor 20 Tahun 2008 tentang Usaha Mikro, Kecil, dan Menengah terdapat beberapa kriteria yang meliputi: Usaha mikro, yaitu usaha menguntungkan yang dioperasikan oleh perorangan dan / atau badan usaha mandiri yang memenuhi persyaratan hukum untuk usaha mikro. Usaha Kecil adalah kegiatan komersial menguntungkan yang berdiri sendiri dan dilakukan oleh perorangan atau organisasi bisnis yang bukan merupakan anak perusahaan atau divisi dari korporasi yang dimiliki, dioperasikan atau menjadi bagian, baik langsung maupun tidak langsung, dari perusahaan menengah atau besar yang sesuai dengan kebutuhan bisnis. yang diatur oleh undang-undang. c. Usaha Menengah: Usaha ekonomi produktif yang mandiri, dilakukan oleh orang atau organisasi perusahaan yang bukan merupakan divisi atau cabang dari suatu korporasi yang dimiliki, dikelola atau sebagian, baik secara langsung maupun secara tidak langsung, dari bisnis 
kecil atau besar dengan nilai bersih total atau pendapatan kotor tahunan sebagaimana diatur oleh undang-undang. Penelitian yang dilakukan oleh Prameswari menunjukkan bahwa masyarakat antusias mengenai penggunaan E-commerce dan banyak konsumen mulai berbelanja online mengingat prosesnya yang mudah dan efisiensi waktu. Berdasarkan hasil penelitian, media e-commerce yang paling banyak digunakan responden adalah media sosial karena mudah untuk diakses. Selain itu, karena respon penjual yang cepat membuat media sosial seperti Facebook, Instagram, Twitter, dll banyak digunakan oleh responden (Prameswari, 2017).

Hasil penelitian menunjukan bahwa sebanyak 25 persen dari total UMKM belum memanfaatkan media sosial baik Facebook maupun Instagram juga e-commerce. 50 persen sudah mulai menggunakan media sosial dan e-commerce. Dan 25 persen lagi menggunakan media sosial dan e-commerce dalam tahapan yang lebih advance artinya pelaku UMKM bidang kuliner tersebut sudah bisa mengoptimalkan fitur-fitur yang ada dalam media sosial seperti Instagram maupun e-commerce seperti GoFood dan GrabFood.

Dari total 40 mitra yang dijadikan sampel dalam penlitian ini, 25 persen yakni sebanyak 20 mitra masih sangat awam dengan media sosial maupun e-commerce. Mereka lebih meyakini penjulan bisa tetap dilakukan secara konvensional, dan mereka pun memiliki pandangan bahwa memiliki smartphone hanya untuk melakukan komunikasi padahal smartphone yang mereka miliki bisa digunakan dan dimanfaatkan untuk kemajuan bisnis atau pemasaran produk melalui pemanfaatan media sosial seperti Instagram dengan berbagai fiturnya yang dapat membantu pelaku UKM menajangkau pangsa pasar yang lebih luas.

Sebanyak 50 persen sudah menggunakan media sosial dan e-commerce untuk memasarkan produknya. Para mitra yang sudah mengunakan medis sosial meyakini bahwa media sosial memberikan kemudahan dalam memasarkan produk dan tentu saja berimplikasi pada peningkatan penjualan. Dan sebanyak 25 persen lagi meyakini bahwa media sosial dan e-commerce seperti instragram dan aplikasi GoFood memudahkan dan menjaga kestabilan penjualan bahkan terjadi peningkatan penjualan dengan mengoptimalkan berbagai fitur yang ada baik di media sosial seperti instragram for bisnis maupun e-commerce seperti GoFood dan GrabFood dengan melakukan promosi seperti promosi potongan harga maupun promosi ongkos kirim. Pemanfaatan media sosial dan e-commerce yang tepat dapat mengurangi cost (biaya) seperti biaya promosi biaya iklan, biaya operasional karyawan, dan tentu saja meningkatkan penjualan. 
Hal tersebut sejalan dengan apa yang diungkapkan oleh salah satu key informant dalam penelitian ini bahwa media sosial Instagram dirasakan memberikan manfaat dalam hal pengenalan porduk bagi konsumen yang selanjutnya mendorong konsumen untuk melakukan pembelian. Menurut (Schiffman \& Kanuk, 2004) pada umumnya, komunikasi pemasaran yang dilakukan perusahaan dirancang agar konsumen mengetahui adanya produk tersebut, mendorong pembelian atau komitmen, menimbulkan sikap yang positif terhadap produk, memberikan arti simbolis kepada produk, atau menunjukkan bagaimana komunikasi tersebut dapat lebih baik dalam memecahkan masalah konsumen jika dibandingkan dengan produk (barang atau jasa) competitor .

"Marketing communications is a management process through which an organisation develops, presents and evaluates a series of messages to identified stakeholders audiences. The objective of the process is to (re)position the organisation and/or their offerings, in the mind of each member of the audience. This seeks to encourage stakeholders to perceive the organisation and its offerings as solutions to some of their current and future problems." (Fill, 1995)

Salah satu informan, yakni dari Ima's cake an bakery telah melakukan hal tersebut dengan

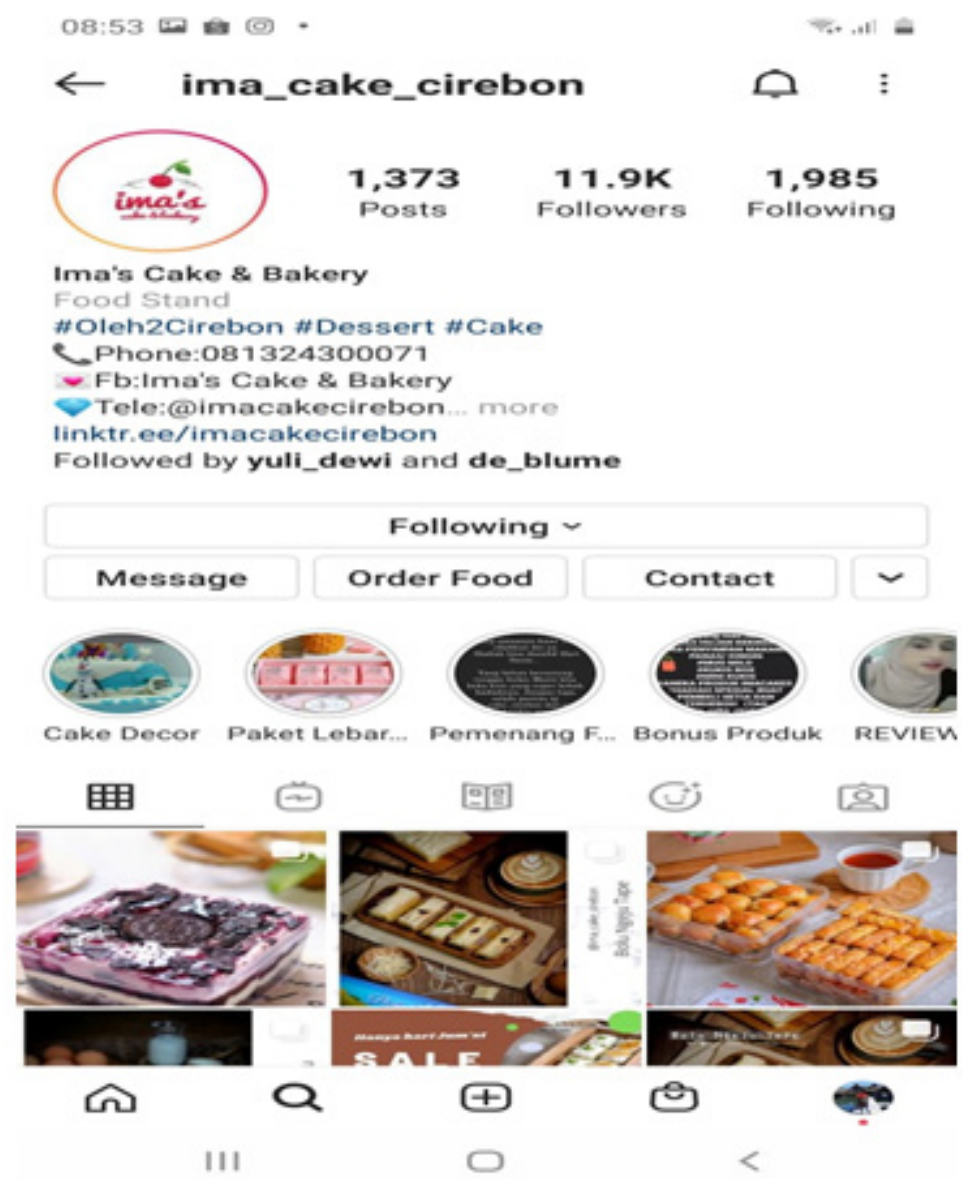

Sumber: Instagram, 2021

Gambar 1 Instagram ima's cake\&bakery 
memfasilitasi calon konsumennya untuk dapat memilih melalui aplikasi mana mereka membeli barang dengan beragam pilihan pembelian bisa melalui aplikasi pesan antar seperti GoFood dan GrabFood juga melalui media sosial seperti Instagram. Keputusan konsumen untuk membeli merek yang dipasarkan, tergantung pada usaha promosi dan komunikasi pemasaran dalam memfasilitasi pembelian (facilitate purchasing). Oleh karena itu, dalam merancang pesan, pemasar harus mampu menciptakan asosiasi yang kuat, disukai, unik antara merek dengan ciri-ciri dan manfaatnya.

Diungkapkan oleh pemilik usaha Imas cake and bakery bahwa dengan melakukan posting foto misal foto para public figure yang pernah mencoba makannanya menjadi kunci agar jumlahfollower di Instagram semakin meningkat yang berimplikasi pada meningkatnya jumlah pesanan. Banyaknya digital marketing yang digunakan oleh perusahaan, membuktikan bahwa digital marketing memiliki banyak kelebihan dan kelebihan. Beberapa keunggulan digital marketing dibandingkan dengan jenis pemasaran konvensional antara lain (Wardhana, 2015): Kecepatan Penyebaran. Strategi pemasaran dengan menggunakan media digital bisa dilakukan dengan sangat cepat, bahkan dalam hitungan detik. Selain itu, DM juga dapat diukur secara real time dan tepat. Kemudahan Evaluasi. Dengan menggunakan media online maka hasil dari kegiatan pemasaran dapat langsung diketahui. Informasi seperti berapa lama produk Anda telah ditonton, berapa banyak orang yang melihat produk Anda, berapa persentase konversi penjualan dari setiap iklan dan sebagainya. Setelah mengetahui informasi semacam ini, barulah Anda bisa mengevaluasi iklan mana yang bagus dan mana yang jelek. Jadi Anda bisa meningkatkan untuk periode berikutnya. Jangkauan lebih luas. Keunggulan berikutnya adalah cakupan geografis PB yang luas. Anda bisa menyebarkan brand atau produk Anda ke seluruh dunia hanya dalam beberapa langkah mudah dengan menggunakan Internet. Murah dan efektif. Tentu saja, pemasaran digital jauh lebih murah dan lebih efektif dibandingkan dengan pemasaran konvensional. Menurut Laporan Pengeluaran Pemasaran Digital Gartner, hingga 40\% dari anggaran pengeluaran telah dihemat. Selain itu, studi tersebut juga menunjukkan bahwa 28 persen usaha kecil akan beralih ke digital karena dinilai lebih sukses. build a brand name. Pemasaran digital membantu Anda membangun nama merek yang baik. Keberadaan dunia maya dengan hadirnya brand Anda sangat penting karena orang akan melakukan pengecekan secara online sebelum membeli barang Anda.

Untuk mengembangkan dan memelihara hubungan dengan pelanggan, yang pertama adalah kita harus selalu aktif dan memastikan 
bahwa konten yang kita masukkan ke media sosial adalah yang terbaru dan segar serta memastikan bahwa kita terlibat dan berinteraksi dengan pelanggan. Kedua, bersikap jujur dan hormati aturan di media sosial, jangan pernah memberikan informasi yang menyesatkan karena akan merugikan perusahaan kita. Ketiga, berikan hal-hal yang menarik, karena tidak ada yang mau rekan percakapan yang membosankan, sehingga yang perlu kita lakukan adalah mendengarkan pelanggan, menemukan apa yang membuat mereka ingin didengar, mendengarkan apa yang membuat mereka tertarik dan nyaman serta mengembangkan konten yang sesuai dengan keinginan mereka. keinginan. Keempat, rendah hati; perlu dikaji keberadaan media sosial karena di luar sana sudah banyak yang mendahului kita dalam menggunakan media tersebut, jangan pernah beranggapan kita lebih mahir dalam menggunakan media sosial. Kelima, Bersikaplah profesional; hindari membuat konten yang terlalu serius dan formal. Dan tidak perlu mempekerjakan penulis atau pembuat konten yang membutuhkan biaya mahal dan tidak takut membuat kesalahan dalam konten.

Pemasaran Digital memiliki beberapa bentuk, antara lain: Website. Ini memainkan peranbesar dalammenunjukkan profesionalisme perusahaan, membantu konsumen mengetahui bisnis, promosi yang efisien dan media bisnis yang mudah. Search Engine Marketing juga merupakan upaya untuk membuat situs web perusahaan mudah ditemukan di sistem mesin pencari. Pemasaran Mesin Pencari dibagi menjadi Pengoptimalan Mesin Telusur (SEO) dan Pemasaran Mesin Telusur (SEM). SEO dilakukan sendiri membutuhkan waktu lebih lama dan lebih murah, sedangkan SEM berbayar tetapi lebih cepat. Social Media Marketing beredar platform di media sosial seperti Facebook dan Twitter karena bisa dilakukan dengan biaya minimal bahkan gratis. Hal ini tentunya dapat meningkatkan brand perusahaan. Online advertising merupakan media promosi melalui internet dengan dikenakan biaya. Ini bisa mendapatkan konsumen lebih cepat dan memuaskan tetapi agak lebih mahal dari tipe sebelumnya. Email marketing digunakan agar dapat memberikan informasi terbaru tentang promosi yang sedang berlangsung atau produk atau layanan terbaru. Video marketing juga digunakan agar mereka bisa langsung menjelaskan tentang bisnisnya, menjelaskan produk dan cara menggunakannya serta menampilkan testimoni pelanggan. Pengelolaan media sosial yang baik tentu nilai tambah sebuah produk di mata konsumennya, lebih jauh meningkatkan penjualan. seperti yang dilakukan oleh ima's cake \& bakery.

Ima's cake and bakery percaya bahwa dengan mengungah foto yang menarik di media 


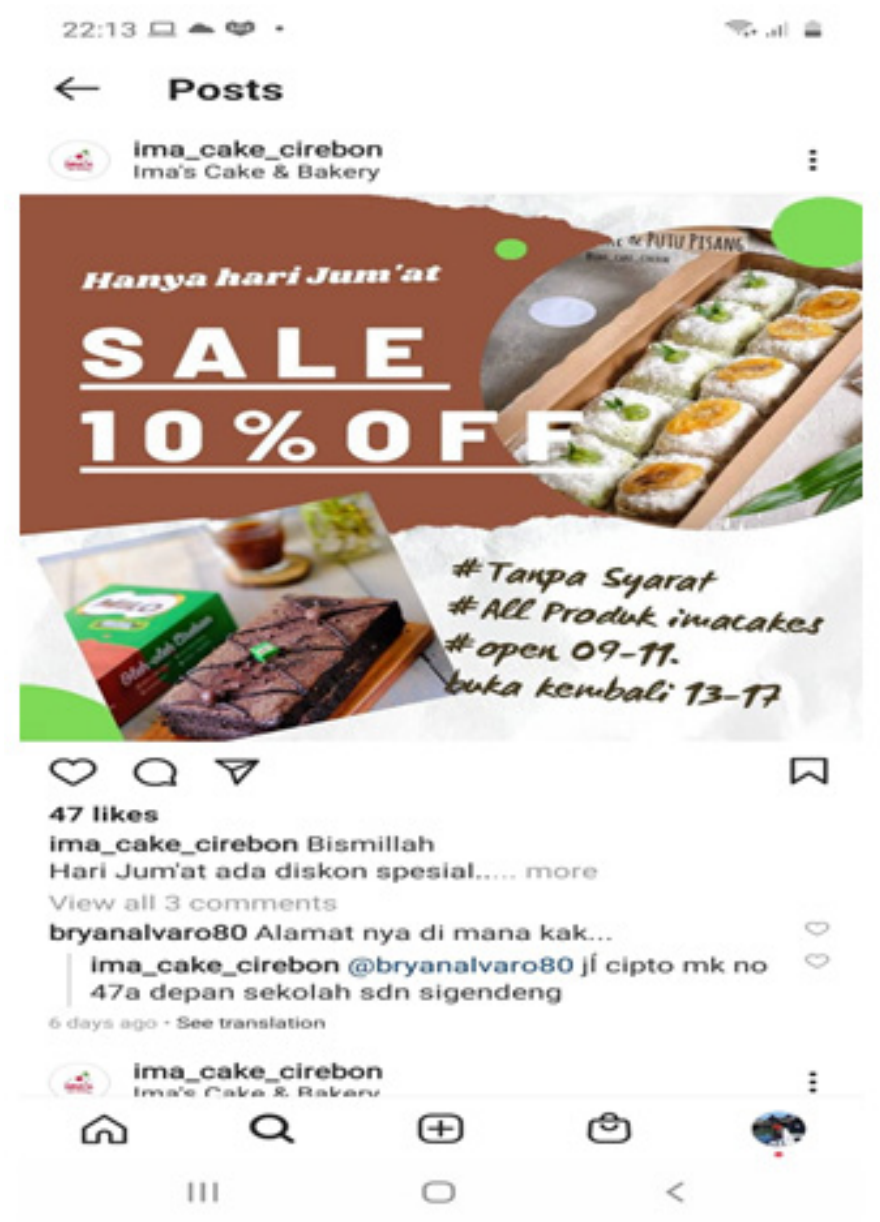

Sumber: Instagram, 2021

Gambar 2 unggahan foto ima's cake\&bakery

sosial Instagram dapat memberikan daya tarik dibenak konsumennya. Selain itu juga adanya interkasi yang dilakukan seperti membalas komentar pun sebagai bagian dari menjalin hubungan yang baik dengan konsumen.

Selain itu duangkapkan oleh account executive Gojek bahwa pemebrian promo oleh para mitra pada aplikasi GoFood memberikan daya tarik tersendiri bagi konsumen, terlebih jika pelaku UMKM memberikan promo bundling dan juga beragam varian menu yang ditawarkan. Hal tersebut sejalan dengan apa yang diungkapkan oleh Kurnia bahwa E-commerce menjadi hal yang penting untuk transaksi dalam kehidupan di abad ke-21 (Kurnia et al., 2015).

Selain itu karakteristik penting yang membedakan lingkungan digital dari lingkungan pemasaran tradisional adalah kemudahan di mana pelanggan dapat berbagi informasi dari mulut ke mulut, tidak hanya dengan beberapa teman dekat tetapi juga dengan orang asing di jaringan sosial yang luas. Di lingkungan digital, pelanggan dapat memposting ulasan tentang produk, layanan, merek, dan perusahaan di situs web perusahaan serta situs web pihak ketiga dan jejaring sosial, dan ulasan ini menjangkau lebih 
banyak calon pelanggan. Para pelaku UMKM yang telah memanfaatkan media sosial dengan baik meyakini bahwa ulasan yang diberikan oleh konsumen yang kemudian dibagikan pada laman Instagramnya memberikan keuntungan tersendiri dimana akan semakin banyak orang yang aware akan keberadaan produk tersebut.

Penelitian yang dilakukan oleh Toubia dan Stephen menujukan bahwa fokus pada pertanyaan motivasi yang penting: why do people contibute in a social media? Penelitian mereka membedakan antara dua jenis utilitas yang diperoleh kontributor dari media sosial: (1) utilitas intrinsik, utilitas langsung dari konten posting, dan (2) utilitas terkait gambar yang berasal dari persepsi orang lain. Kedua jenis utilitas ini dapat dibedakan secara empiris karena yang pertama bergantung pada perilaku posting sedangkan yang terakhir hanya terkait dengan jumlah pengikut yang dimiliki seseorang di jejaring sosial. Dalam percobaan lapangan mereka, Toubia dan Stephan secara acak memilih 100 pengguna non-komersial aktif di Twitter dan menambahkan 100 pengikut sintetis ke setiap pengguna selama periode 50 hari. Mereka menemukan utilitas intrinsik melebihi utilitas terkait gambar ketika pengguna Twitter memiliki lebih sedikit pengikut, sedangkan utilitas terkait gambar menjadi lebih dominan karena pengguna Twitter mengumpulkan lebih banyak pengikut. Selain itu, utilitas terkait gambar lebih besar daripada utilitas intrinsik untuk sebagian besar pengguna (Toubia \& Stephen, 2013).

Pemanfaatan e-commerce seperti GoFood juga memberikan banyak keuntungan bagi produsen atau pelaku UMKM yakni pelaku UMKM dengan mudah mendapatkan feedback dari konsumennya sebagai contoh rating bulanan yang diberikan oleh konsumen akan membuat pelaku UMKM melakukan evaluasi dengan mudah. Adanya laporan rating bulanan yang diberikan kepada mitra disetiap bulannya memudahkan para pelaku UMKM bidang kuliner untuk melakukan evaluasi dalam rangka perbaikan dari sisi produk, pengemasan, komposisi bahan dan lain sebagainya.

Pandemi Covid19 ini adalah masa sulit UMKM. Namun bukan berarti tidak ada yang bertahan atau bahan bertumbuh. UMKM yang mampu bertahan dan bertumbuh pada masa pandemi ini adalah mereka yang masuk pada ekosistem digital menurut (Diez-Martin et al., 2019).

Pelaku UMKM bidang kuliner sudah mulai menggunakan media sosial seperti Instagram dan e-commerce seperti Gofood dan GrabFood untuk memasarkan produknya, beberapa pelaku UMKM bahkan sudah sangat menguasai berbagai fitur yang ada di sosial media seperti Instagram yang diperuntukan untuk bisnis, pengelolaan media sosial dan e-commerce yang 


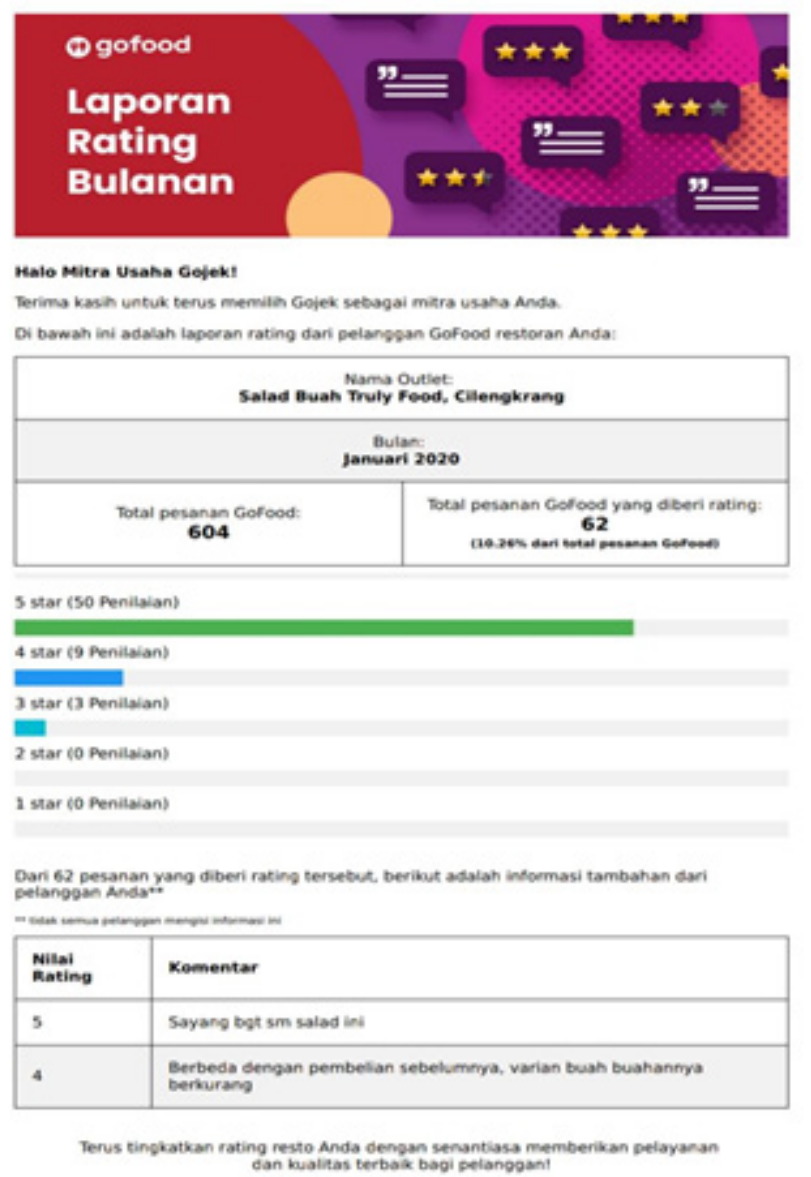

Sumber: dokumentasi Truly Food, 2020

\section{Gambar 3 Rating Bulanan Truly Food (Mitra UMKM)}

baik pun dapat mengingkatkan omset penjualan di tengah pandemi covid-19 yang terjadi saat ini, sumberdaya yang dimiliki pelaku UMKM menjadi salah satu faktor yang menentukan bagaiman media sosial dan e-commerce ini dapat di kelola dengan baik yang berimplikasi pada kemungkinan terjadinya kenaikan omset.

\section{SIMPULAN}

Para pelaku UMKM memegang pernan vital bagiperekonomiandiIndonesiakhususnyadalam hal ini ialah di Jawa Barat. Pandemi covid-19 telah memporak-porandakanperekonomian di Indonesia. Sektor UMKM paling terpengaruh karena sektor ini sangat bergantung pada pergerakan perekonomian sehari-hari. Adanya pembatasan kegiatan yang dilakukan oleh pemerintah menyebabkan perputaran ekonomi menjadi tersendat. Perlu adanya inovasi dari para pelaku UMKM juga pemerintah agar sektor UMKM ini tetap bisa bertahan bahkan berkembang ke arah yang lebih baik. Perkembangan Internet of Thing, khususnya pada platform media sosial seperti instagram telah menjadi ajang dan peluang baru bagi para pelaku UMKM. Peluang area pemasaran yang tidak terbatas harus dimanfaatkan dengan baik oleh para pelaku UMKM. Namun pada 
kenyataannya masih sangat sedikit sektor UMKM yang memanfaatkan media sosial dan e-commerce dalam mesarakna produknya. Hal ini tentunya menjadi catatan tersendiri bagi pemerintah dan semua pihak yang terlibat di sektor ini bagaimana para pelaku UMKM tersebut dapat berperan penuh memanfaatkan konsep digital marketing ini sehingga berdampak pada peningkatan omset yang pada akhirnya dapat membuat pelaku sektor UMKM bertahan di tengah pandemi COVID-19 seperti sekarang ini. Para pelaku UMKM harus bisa merancang pesan promosi dengan baik, menggunakan media sosial seperti instagram dan mengoptimalkan penggunaan e-commerce denngan program promosi yang menarik dan tentu saja harus memiliki jiwa kreativitas yang tinggi agar rancangan pesan promosi yang dibuat baik di media sosial instagram maupun e-commerce berkesinambungan dan menarik minat konsumen yang pada akhirnya terjadi pembelian berulang.

\section{DAFTAR PUSTAKA}

Batubara, A., \& Hidayat, R. (2016). Pengaruh Penetapan Harga dan Promosi terhadap Tingkat Penjualan Tiket pada PSA Mihin Lanka Airlines. Jurnal Ilman, 4(1), 33-46.

Boyd, H. W. (2000). Manajemen Pemasaran "suatu pendekatan strategis dengan orientasi global." Erlangga.

Consulting, B. (2020). What Nation Brands must do to tackle Covid-19. Bloom Consulting
Journal. https://www.bloom-consulting. com/journal/what-nation-brands-must-doto-tackle-covid-19/

Creswell, J. W. (2018). Qualitative inquiry and research design: Choosing among five traditions (p. 14). SAGE Publications, Inc.

Cummins, J. (1991). Promosi Penjualan. Binarupa Aksara.

Diez-Martin, F., Blanco-Gonzalez, A., \& PradoRoman, C. (2019). Research challenges in digital marketing: Sustainability. Sustainability (Switzerland), 11(10). https://doi.org/10.3390/su11102839

Dirgantara, H. B., \& Sambodo, A. T. (2015). Penerapan model importance performance analysis dalam studi kasus: analisis kepuasan konsumen bhinneka. com. Jurnal Sains Dan Teknologi Kalbis Scientia, 2(1), 52-62. http://research. kalbis.ac.id/Research/Files/Article/Full/ canw18mbtpov14niqwgnia6h1.pdf

Febriyantoro, M. T., \& Arisandi, D. (2018). Debby Arisandi Halaman 61 dari 76 JMD. Jurnal Manajemen Dewantara, 1(2), 6176.

Fill, C. (1995). Marketing Communications, Framework, Theories, Applications. Prentice Hall.

Harnani, S. (2020). Efektivitas Pembelajaran Daring Di Masa Pandemi Covid-19. Bdkjakarta.Kemenenag.Go.Id. https:// bdkjakarta.kemenag.go.id/berita/ efektivitas-pembelajaran-daring-di-masapandemi-covid-19

Jabarprov.go.id. (2020). UMKM-Bakal-JadiAndalan-Pertumbuhan-Ekonomi-di-Era$A K B$. Jabarprov.Go.Id.

Kannan, P. K., \& Li, H. “Alice." (2017). Digital marketing: A framework, review and research agenda. International Journal of Research in Marketing, 
34(1), 22-45. https://doi.org/10.1016/j. ijresmar.2016.11.006

Kaplan, A. M., \& Haenlein, M. (2010). Users of the world, unite! The challenges and opportunities of Social Media. Business Horizons, 53(1), 59-68. https://doi. org/10.1016/j.bushor.2009.09.003

Kotler, P. (2014). Manajemen Pemasaran Edisi Bahasa Indonesia jilid satu. Prentice Hall.

Kurnia, S., Choudrie, J., Mahbubur, R. M., \& Alzougool, B. (2015). E-commerce technology adoption: A Malaysian grocery SME retail sector study. Journal of Business Research, 68(9), 1906-1918. https://doi. org/10.1016/j.jbusres.2014.12.010

Nguyen, H., \& Pham, T. (2020). Is COVID-19 an opportunity to strengthen online teaching? Nurpratama, M. (2020). Penerapan digital marketing bagi usaha mikro, kecil dan menengah (Umkm) Di Kelurahan Karangmalang Indramayu. Jurnal Investasi, 6(2).

Prameswari, N. S., Suharto, M., \& Afatara, N. (2017). Developing E-Commerce for Micro Small Medium Enterprise (MSME) to Cope with Cultural Transformation of Online Shopping. Jurnal Dinamika Manajemen, 8(2), 188-198. https://doi. org/10.15294/jdm.v8i2.12759

Rahadi, D. R. (2017). Perilaku Pengguna Dan Informasi Hoax Di Media Sosial. Jurnal Manajemen Dan Kewirausahaan, 5(1), 58-70. https://doi.org/10.26905/jmdk. v5i1.1342

Santoso, R. (2020). Review of Digital Marketing \& Business Sustainability of E-Commerce During Pandemic Covid19 In Indonesia. Jurnal Ilmu Ekonomi Terapan, 5(2), 36-48. Satyo, F. (2009). Intellectual Capital. Gramedia Pustaka Utama.

Schiffman \& Kanuk. (2004). Perilaku
Konsumen (edisi 7). Prentice Hall.

Shintarani, E. D. (2018). Pengaruh Promosi Produk Seafoodking terhadap Brand awareness Produk. Nyimak (Journal of Communication), 1(2), 209-220. https:// doi.org/10.31000/nyimak.v1i2.484

Soei, C. N., \& Abijono, H. (2014). Penentuan Harga Jual Produk Dengan Menggunakan Metode Cost Plus Pricing Pada Ud. Sinar Sakti. Jurnal EMBA, 2(3), 208-217.

Soetjipto, N. (2020). Ketahanan UMKM Jawa

Timur Melintasi Pandemi COVID-19. K-Media.

Sugiri, D. (2020). Menyelamatkan Usaha Mikro, Kecil dan Menengah dari Dampak Pandemi Covid-19. Fokus Bisnis : Media Pengkajian Manajemen Dan Akuntansi, 19(1), 76-86. https://doi.org/10.32639/ fokusbisnis.v19i1.575

Supriyono. (2020). Media Sosial Sebagai Alat Promosi Yang Efektif Bagi Usaha Rintisan di Era Normal Baru. Prosiding Seminar Stiami, 21(1), 1-9.https://doi.org/10.1016/j. tmaid.2020.101607\%0Ahttps://doi. org/10.1016/j.ijsu.2020.02.034\%0Ahttps:// onlinelibrary.wiley.com/doi/abs/10.1111/ cjag.12228\%0Ahttps://doi.org/10.1016/j. ssci.2020.104773\%0Ahttps://doi. org/10.1016/j.jinf.2020.04.011\%0Ahttps:// doi.o

Swastha, B. (2002). Manajemen Pemasaran. Liberty.

Tjiptono. (2002). Pengaruh Bauran Promosi Terhadap Keputusan Pembelian (Survei pada Mahasiswa Jurusan Bisnis Angkatan 2010-2012 Fakultas Ilmu Administrasi Pengguna Indosat di Universitas Brawijaya). Jurnal Administrasi Bisnis S1 Universitas Brawijaya, 9(2), 222.

Toubia, O., \& Stephen, A. T. (2013). Intrinsic vs. image-related utility in social media: Why 
do people contribute content to Twitter? Marketing Science, 32(3), 368-392. https:// doi.org/10.1287/mksc.2013.0773

Wardhana, A. (2015). Strategi Digital Marketing dan Implikasinya Pada Keunggulan Bersaing UMK di Indonesia. In Seminar Nasional Keuangan Dan Bisnis IV, April 2015, 327-337. 